\title{
EXISTENCE OF A SOLUTION FOR A GENERAL ORDER BOUNDARY VALUE PROBLEM USING THE LERAY-SCHAUDER FIXED POINT THEOREM
}

\author{
Nicola Fabiano ${ }^{a}$, Vahid Parvaneh ${ }^{\mathrm{b}}$ \\ a Independent researcher, Rome, Italy, \\ e-mail: nicola.fabiano@gmail.com, corresponding author, \\ ORCID iD: (1)https://orcid.org/0000-0003-1645-2071 \\ ${ }^{b}$ Islamic Azad University, Department of Mathematics, \\ Gilan-E-Gharb Branch, Gilan-E-Gharb, Islamic Republic of Iran, \\ e-mail: zam.dalahoo@gmail.com, \\ ORCID iD: (1) https://orcid.org/0000-0002-3820-3351
}

DOI: 10.5937/vojtehg69-29703; https://doi.org/10.5937/vojtehg69-29703

FIELD: Mathematics

ARTICLE TYPE: Original scientific paper

\section{Abstract:}

Introduction/purpose: This paper illustrates the existence of a generic Green's function for a boundary value problem of arbitrary order that appears in many phenomena of heat convection, e.g. in the atmosphere, in the oceans, and on the Sun's surface.

Methods: A fixed point theorem in the Leray-Schauder form has been used to establish the existence of a fixed point in the problem.

Results: The existence of a solution has been shown for an arbitrary order of the problem. Some practical examples are proposed.

Conclusions: The boundary problem has a solution for an arbitrary order $n$.

Key words: fixed point, boundary value problem, Leray-Schauder fixed point theorem. 


\section{The problem}

We consider the generic differential equation of order $2 n, n \geq 1$, with the boundary conditions:

$$
\left\{\begin{aligned}
y^{(2 n)}(x) & =\chi\left(x, y(x), y^{\prime \prime}(x)\right) \\
y^{(0)}(0) & =y^{(1)}(0)=\ldots=y^{(n)}(0)=0 \\
y^{(n+1)}(1) & =y^{(n+2)}(1)=\ldots=y^{(2 n-1)}(1)=0 .
\end{aligned}\right.
$$

This kind of equations occurs, for instance, when studying the problem of the beginning of thermal instability in horizontal layers of fluid heated from below. This kind of phenomena could be observed in convection patterns in several situations, for instance, in the atmosphere, in the oceans, when considering the coupling with a strong electromagnetic field, or on the Sun's surface (Chandrasekhar, 1961). This work will extend the results of (Fabiano et al, 2020), (Ahmad \& Ntouyas, 2012) and (Ma, 2000) to an equation of a generic order $2 n$.

Introduce the Green's functions $G_{l}(x, s, n)$ and $G_{r}(x, s, n)$ of problem (1) where $G_{l}(x, s, n)$ is defined for $0 \leq x<s \leq 1$ and $G_{r}(x, s, n)$ is defined for $0 \leq s<x \leq 1,(x, s) \mapsto G_{l, r}(x, s, n) ;(x, s) \in[0,1] \times[0,1], G_{l, r} \in C^{2 n}$ over $\mathbb{R}$ such that solve the following equation:

$$
\left(\frac{\partial}{\partial x}\right)^{2 n} G_{l, r}(x, s, n)=\delta(s-x) .
$$

The complete Green's function is thus obtained by the linear combination of the above two,

$$
G(x, s, n)=\theta(s-x) G_{l}(x, s, n)+\theta(x-s) G_{r}(x, s, n),
$$

$\theta$ is the Heaviside step function. Given the inhomogeneous problem solved by $x \mapsto f(x), x \in[0,1], f \in C$ over $\mathbb{R}$,

$$
\left\{\begin{aligned}
y^{(2 n)}(x) & =f(x) \\
y^{(0)}(0) & =y^{(1)}(0)=\ldots=y^{(n)}(0)=0 \\
y^{(n+1)}(1) & =y^{(n+2)}(1)=\ldots=y^{(2 n-1)}(1)=0,
\end{aligned}\right.
$$

the Green's function provides solution to (4) in the integral form

$$
y(x)=\int_{0}^{1} G(x, s, n) f(s) d s .
$$


The functions $G_{l, r}(x, s, n)$ are multivariate polynomials in two variables $x$ and $s$ of the order $2 n-1$ to be sought in the form

$$
G_{l}(x, s, n)=\sum_{k=1}^{n} c(k, n) x^{k-1} s^{2 n-k}
$$

and

$$
G_{r}(x, s, n)=\sum_{k=1}^{n} c(k, n) s^{k-1} x^{2 n-k}
$$

where the coefficient $c(k, n)$ is clearly given in combinatoric terms, $k \leq n$.

Imposing boundary conditions (4) to the Green's function, we obtain that

$$
G_{l}(0, s, n)=\left.\left(\frac{\partial}{\partial x}\right) G_{l}(x, s, n)\right|_{x=0}=\ldots=\left.\left(\frac{\partial}{\partial x}\right)^{n} G_{l}(x, s, n)\right|_{x=0}=0
$$

and

$$
\left.\left(\frac{\partial}{\partial x}\right)^{n+1} G_{r}(x, s, n)\right|_{x=1}=\ldots=\left.\left(\frac{\partial}{\partial x}\right)^{2 n-1} G_{r}(x, s, n)\right|_{x=1}=0 .
$$

So, we could infer the following results.

For $G_{l}(x, s, n)$ the powers of $x$ range from $n$ to $2 n-1$, while for the powers of $s$ we have the range from 0 to $n-1$. For $G_{r}(x, s, n)$ we find the same situation when swapping $s$ with $x$. Therefore, the coefficient $c(k, n)$ has to be symmetric under this exchange.

We conclude that the coefficient $c(k, n)$ of both functions $G_{l, r}(x, s, n)$ is given by:

$$
c(k, n)=\frac{(-1)^{k}}{(2 n-1) !}\left(\begin{array}{c}
2 n-1 \\
k-1
\end{array}\right)=\frac{(-1)^{k}}{(k-1) !(2 n-k) !} .
$$

Notice that $|c(k, n)|<1$ for all $k, n$. This observation will be useful in the sequel.

The resulting Green's function $G(x, s, n)$ and its $x$ derivatives are continuous up to order $2 n-2$, and present the discontinuity in -1 at order $2 n-1$, because of the Dirac's $\delta$ function.

The above discussion concludes the proof of the following lemma:

Lemma 1. Let $x \mapsto y(x), x \in[0,1]$ be a function of class $C^{2 n}$ in $\mathbb{R}$, let $(x, y, z) \mapsto \chi(x, y, z) ; x \in[0,1],(y, z) \in \mathbb{R}^{2}$ be a function of class $C$ in $\mathbb{R}$ and 
let $\chi$ be a function of class $C$ in $\mathbb{R}$. Then the Green's function of the problem (4) obeying to equation (2) is given by formulas (3), (6), (7), and (10).

Another property of these Green's functions is their homogeneity. In fact, under the scaling transformation $(x, s) \rightarrow(\alpha x, \alpha s)$ for $\alpha>0$ one has

$$
G_{l, r}(\alpha x, \alpha s, n)=\alpha^{2 n-1} G_{l, r}(x, s, n),
$$

that is, $G_{l, r}(x, s, n)$ is homogeneous of degree $2 n-1$.

\section{Solution}

In this section, we will provide the main result of this work: the solution of the problem in (1) for a generic $n$.

Define the integral operator $\Upsilon$ as follows:

$$
\Upsilon y(x):=\int_{0}^{x} G_{r}(x, s, n) f(s) d s+\int_{x}^{1} G_{l}(x, s, n) f(s) d s .
$$

According to Lemma 1, this operator provides a solution of problem (4) for a generic order $n$ provided that it has a fixed point.

We shall make use of the following theorem of (Bekri \& Benaicha, 2018) and (Shanmugam et al, 2019), the Leray-Schauder form of the fixed point theorem appears in (Isac, 2006), (Deimling, 1985) and (Zvyagin \& Baranovskii, 2010):

THEOREM 1. Let $(E,\|\cdot\|)$ be a Banach space, let $U \subset E$ be an open bounded subset for which $0 \in U$ and let $\Upsilon: \bar{U} \rightarrow E$ be a completely continuous operator. Then only one of the following possibilities is true:

1. $\Upsilon$ possesses a fixed point $\bar{x} \in \bar{U}$

2. there exist an element $x \in \partial \bar{U}$ and a real number $\lambda>1$ such that $\Upsilon x=\lambda x$.

Therefore, in order to establish the existence of a solution it is necessary to prove that our integral operator $\Upsilon$ possesses a fixed point. The following two theorems are devoted to this problem.

THEOREM 2. Let $x \mapsto y(x), x \in[0,1]$ be a function of class $C^{2 n}$ in $\mathbb{R}$, let $(x, y, z) \mapsto \chi(x, y, z) ; x \in[0,1],(y, z) \in \mathbb{R}^{2}$ be a function of the class $C$ in $\mathbb{R}$ 
and $|\chi(x, 0,0)| \neq 0$. Suppose that there exist three nonnegative functions $x \mapsto(u(x), v(x), w(x)) \in L^{1}[0,1]$ such that

$$
|\chi(x, y, z)| \leq u(x)|y|+v(x)|z|+w(x) .
$$

Define the kernel

$$
\mathcal{K}_{n}(s):=\sum_{k=1}^{2 n-1} s^{k}
$$

and suppose that

$$
A:=\int_{0}^{1} \mathcal{K}_{n}(s)[u(s)+v(s)] d s<1 .
$$

Then the problem (1) has at least one nontrivial solution $x \mapsto \xi(x), x \in[0,1]$ of class $C^{2 n}$ in $\mathbb{R}$.

Proof. Define the constant

$$
B=\int_{0}^{1} \mathcal{K}_{n}(s) w(s) d s .
$$

From our hypothesis $A<1$ and $w(s) \geq 0$. Observe that $\mathcal{K}_{n}(s)>0$ for all $s \in[0,1]$. As $|\chi(x, y, z)| \leq u(x)|y|+v(x)|z|+w(x)$, for all $x \in[0,1]$ and $(y, z) \in \mathbb{R}^{2}$ and according to the fact that $\chi(x, 0,0) \neq 0$ for all $x \in[0,1]$, there exist an interval $[a, b] \subset[0,1]$ such that $\max _{x \in[a, b]}|\chi(x, 0,0)|>0$. Therefore, $|\chi(x, 0,0)|>0$ and also $w(x)>0$, for some $x \in[a, b] \subset[0,1]$. This implies the inequality $\int_{0}^{1} \mathcal{K}_{n}(s) w(s) d s \geq \int_{a}^{b} \mathcal{K}_{n}(s) w(s) d s>0$. We conclude that $A<1$ and $B>0$.

Define $L:=B(1-A)^{-1}$ which is positive by construction, and the set $U=\{y \in E:\|y\|<L\}$. Assume that $y \in \partial U$ and $\lambda>1$. As $\Upsilon y=\lambda y$, then $\lambda L=\lambda\|y\|=\|\Upsilon y\|=\max _{x \in[0,1]}|(\Upsilon y)(x)|$. Adopting the simplified notation $d \mu=\mid \chi\left(s, y(s), y^{\prime \prime}(s) \mid d s\right.$ we have:

$$
\begin{gathered}
\lambda L=\max _{x \in[0,1]}|(\Upsilon y)(x)| \leq\left\{\int_{0}^{x} G_{r}(x, s, n) d \mu+\int_{x}^{1} G_{l}(x, s, n) d \mu\right\}= \\
\sum_{k=1}^{n} c(k, n)\left\{\int_{0}^{x} s^{k-1} x^{2 n-k} d \mu+\int_{x}^{1} x^{k-1} s^{2 n-k} d \mu\right\} \leq
\end{gathered}
$$




$$
\begin{gathered}
\sum_{k=1}^{n} c(k, n) \max _{x \in[0,1]}\left\{\int_{0}^{x} s^{k-1} x^{2 n-k} d \mu+\int_{x}^{1} x^{k-1} s^{2 n-k} d \mu\right\}= \\
\sum_{k=1}^{n} c(k, n)\left\{\int_{0}^{1} s^{k-1} d \mu+\int_{0}^{1} s^{2 n-k} d \mu\right\}= \\
\sum_{k=1}^{n} c(k, n)\left\{\int_{0}^{1}\left(s^{k-1}+s^{2 n-k}\right) d \mu\right\} \leq \\
\sum_{k=1}^{n}\left\{\int_{0}^{1}\left(s^{k-1}+s^{2 n-k}\right) d \mu\right\}=\sum_{k=1}^{2 n-1} \int_{0}^{1} s^{k} d \mu=\int_{0}^{1} \mathcal{K}_{n}(s) d \mu .
\end{gathered}
$$

from our hypothesis, $|\chi(x, 0,0)|$ has an upper bound for all $x \in[0,1]$. So, one has

$$
\begin{gathered}
\int_{0}^{1} \mathcal{K}_{n}(s)|\chi(s, 0,0)| d s \leq \int_{0}^{1} \mathcal{K}_{n}(s)\left[u(s)|y(s)|+v(s)\left|y^{\prime \prime}(s)\right|+w(s)\right] d s \leq \\
\int_{0}^{1} \mathcal{K}_{n}(s)\left[u(s) \max _{s \in[0,1]}|y(s)|+v(s) \max _{s \in[0,1]}\left|y^{\prime \prime}(s)\right|+w(s)\right] d s \leq \\
\int_{0}^{1} \mathcal{K}_{n}(s)\left[u(s)|y(s)|_{\infty}+v(s)\left|y^{\prime \prime}(s)\right|_{\infty}+w(s)\right] d s \leq \\
\int_{0}^{1} \mathcal{K}_{n}(s)[u(s)\|y\|+v(s)|| y \|+w(s)] d s= \\
\int_{0}^{1} \mathcal{K}_{n}(s)[u(s)+v(s)]\|y\| d s+\int_{0}^{1} \mathcal{K}_{n}(s) w(s) d s= \\
A\|y\|+B=A L+B
\end{gathered}
$$

Using equation (12), we obtain the bound $\lambda L \leq A L+B$ which implies that

$$
\lambda \leq A+\frac{B}{L}=A+\frac{B}{B(1-A)^{-1}}=1,
$$

which contradicts the hypothesis for which $\lambda>1$, that is point (2) of Theorem 2.1 is ruled out, while point (1) is fulfilled. Therefore, we conclude that there exists at least a nontrivial solution $\xi(x)$ of problem (1).

Up to this point, we have established the existence of a solution for the boundary value problem. In the following theorem, we show some parameter dependent bounds that actually lead to the existence of a solution. 
THEOREM 3. Let $(x, y, z) \mapsto \chi(x, y, z) ; x \in[0,1],(y, z) \in \mathbb{R}^{2}, \chi$ is of class $C$ in $\mathbb{R}$ and $|\chi(x, 0,0)| \neq 0$. Suppose that there exist three nonnegative functions $x \mapsto(u(x), v(x), w(x)) \in L^{1}[0,1]$ such that

$$
|\chi(x, y, z)| \leq u(x)|y|+v(x)|z|+w(x) .
$$

Define

$$
\mathcal{K}_{n}(s):=\sum_{k=1}^{2 n-1} s^{k}
$$

and suppose that either one of the following conditions holds:

1. There exists a constant $\ell>-2$ such that

$$
u(s)+v(s)<\frac{s^{\ell}}{\psi(2 n+\ell+1)-\psi(\ell+2)}, 0 \leq s \leq 1
$$

where

$$
\psi(z):=\frac{d}{d z}[\log \Gamma(z)] \text { and } \Gamma(z):=\int_{0}^{\infty} e^{-t} t^{z-1} d t .
$$

2. There exists a constant $m>-1$ such that

$$
u(s)+v(s)<\frac{m^{2}+m}{1-\left(m^{2}+m\right) \beta(m, 2 n+1)} \cdot(1-s)^{m}, 0 \leq s \leq 1,
$$

where

$$
\beta(m, 2 n+1)=\frac{\Gamma(m) \Gamma(2 n+1)}{\Gamma(2 n+m+1)} .
$$

3. There exists a constant $a>1$ such that

$$
\left[\int_{0}^{1}(u(s)+v(s))^{a} d s\right]^{\frac{1}{a}}<\frac{1}{\sum_{k=1}^{2 n-1}\left(\frac{1}{k b+1}\right)^{\frac{1}{b}}}, \frac{1}{a}+\frac{1}{b}=1
$$

and

$$
\int_{0}^{1} \mathcal{K}_{n}(s)[u(s)+v(s)] d s<1
$$

Then problem (1) has at least one nontrivial solution $x \mapsto \xi(x), x \in[0,1]$ of class $C^{2 n}$ in $\mathbb{R}$. 
Proof. In order to prove this theorem, one has to show that the integral operator (11) has $A<1, A$ being defined in Theorem 2 .

To prove point 1 , we proceed as follows:

$$
\begin{gathered}
\int_{0}^{1} \mathcal{K}_{n}(s)[u(s)+v(s)] d s<\frac{1}{\psi(2 n+\ell+1)-\psi(\ell+2)} \int_{0}^{1} \mathcal{K}_{n}(s) s^{\ell} d s= \\
\frac{1}{\psi(2 n+\ell+1)-\psi(\ell+2)} \sum_{k=1}^{2 n-1} \int_{0}^{1} s^{(k+\ell)} d s= \\
\frac{1}{\psi(2 n+\ell+1)-\psi(\ell+2)} \sum_{k=1}^{2 n-1} \frac{1}{k+\ell+1}= \\
{[\psi(2 n+\ell+1)-\psi(\ell+2)] \cdot \frac{1}{\psi(2 n+\ell+1)-\psi(\ell+2)}=1,}
\end{gathered}
$$

and when $\ell>-2$, one has

$$
\frac{1}{\psi(2 n+\ell+1)-\psi(\ell+2)}>0 .
$$

For point 2, we have

$$
\begin{gathered}
\int_{0}^{1} \mathcal{K}_{n}(s)[u(s)+v(s)] d s<\frac{m^{2}+m}{1-\left(m^{2}+m\right) \beta(m, 2 n+1)} \int_{0}^{1} \mathcal{K}_{n}(s)(1-s)^{m} d s= \\
\frac{m^{2}+m}{1-\left(m^{2}+m\right) \beta(m, 2 n+1)} \sum_{k=1}^{2 n-1} \int_{0}^{1} s^{k}(1-s)^{m} d s= \\
\frac{m^{2}+m}{1-\left(m^{2}+m\right) \beta(m, 2 n+1)} \sum_{k=1}^{2 n-1} \beta(k, m)= \\
{\left[\frac{m^{2}+m}{1-\left(m^{2}+m\right) \beta(m, 2 n+1)}\right] \cdot\left[\frac{1}{m^{2}+m}-\beta(m, 2 n+1)\right]=1, \quad \text { (15) }}
\end{gathered}
$$

and when $m>-1$, one has

$$
\frac{m^{2}+m}{1-\left(m^{2}+m\right) \beta(m, 2 n+1)}>0 .
$$

In the case of point 3 , we make use of Hölder inequality for which $\int_{S}|f(s) g(s)| d s \leq\left(\int_{S}|f(s)|^{a} d s\right)^{1 / a}\left(\int_{S}|g(s)|^{b} d s\right)^{1 / b}$, whenever $f$ and $g$ are measurable functions on the domain $S$ and $1 / a+1 / b=1$. We have 


$$
\begin{gathered}
\int_{0}^{1} \mathcal{K}_{n}(s)[u(s)+v(s)] d s \leq \\
{\left[\int_{0}^{1}(u(s)+v(s))^{a} d s\right]^{\frac{1}{a}} \cdot \sum_{k=1}^{2 n-1}\left[\int_{0}^{1}\left(s^{k}\right)^{b} d s\right]^{\frac{1}{b}}=} \\
\frac{1}{\sum_{k=1}^{2 n-1}\left(\frac{1}{k b+1}\right)^{\frac{1}{b}}} \cdot \sum_{k=1}^{2 n-1}\left(\frac{1}{k b+1}\right)^{\frac{1}{b}}=1
\end{gathered}
$$

\section{Examples}

\section{Example 1}

Consider the problem for a generic $n \geq 1$

$$
\left\{\begin{aligned}
y^{(2 n)}(x) & =\frac{x^{\alpha}}{2} y^{2} e^{-y^{2}}+\frac{x^{\alpha}}{8} \frac{\left(y^{\prime \prime}\right)^{4}}{\left[\left(y^{\prime \prime}\right)^{6}+2\right]} \sin y^{\prime \prime}+e^{-\frac{x^{2}}{2}} \\
y^{(0)}(0) & =y^{(1)}(0)=\ldots y^{(n)}(0)=0 \\
y^{(n+1)}(1) & =y^{(n+2)}(1)=\ldots y^{(2 n-1)}(1)=0
\end{aligned}\right.
$$

This problem satisfies all requirements of Theorem 2. In fact, one has

$$
\chi(x, y, z)=\frac{x^{\alpha}}{2} y^{2} e^{-y^{2}}+\frac{x^{\alpha}}{8} \frac{z^{4}}{z^{6}+2} \sin z+e^{-\frac{x^{2}}{2}}
$$

together with

$$
u(x)=\frac{x^{\alpha}}{2}, v(x)=\frac{x^{\alpha}}{2}, w(x)=e^{-\frac{x^{2}}{2}} .
$$

For a generic $\alpha>0$, following Theorem 3, hypothesis 1 , we have that $(u(x), v(x), w(x)) \in L^{1}[0,1]$ are nonnegative functions. Moreover,

$$
|\chi(x, y, z)| \leq u(x)|y|+v(x)|z|+w(x)
$$

for all $x \in[0,1]$ and for all $(y, z) \in \mathbb{R}^{2}$. 
Setting $\alpha=\ell$ one has to consider the inequality

$$
\left[\frac{1}{\psi(2 n+\ell+1)-\psi(\ell+2)}-1\right] x^{\ell}>0
$$

for all $x \in[0,1]$. In the parameter space $(\alpha, \ell, n)$, the above inequality is satisfied, for instance, for the case $\alpha=\ell=n$, whenever

$$
1 \leq n \leq 12
$$

In this case, the existence of a nontrivial solution $\xi(x) \in C^{2 n}[0,1]$ is guaranteed for problem (17).

\section{Example 2}

Consider the problem for a generic $n \geq 1$

$$
\left\{\begin{aligned}
y^{(2 n)}(x) & =\frac{1}{4}(1-x)^{\alpha} y \cos y+\frac{1}{32}(1-x)^{\alpha} y^{\prime \prime} \tanh y^{\prime \prime}+\cosh x \\
y^{(0)}(0) & =y^{(1)}(0)=\ldots=y^{(n)}(0)=0 \\
y^{(n+1)}(1) & =y^{(n+2)}(1)=\ldots=y^{(2 n-1)}(1)=0 .
\end{aligned}\right.
$$

This problem satisfies all requirements of Theorem 2. In fact, one has

$$
\chi(x, y, z)=\frac{1}{4}(1-x)^{\alpha} y \cos y+\frac{1}{32}(1-x)^{\alpha} z \tanh z+\cosh x
$$

together with

$$
u(x)=\frac{(1-x)^{\alpha}}{2}, v(x)=\frac{(1-x)^{\alpha}}{2}, w(x)=\cosh x .
$$

For a generic $\alpha>0$, from hypothesis 2 of Theorem 3, we have that $(u(x), v(x), w(x)) \in L^{1}[0,1]$ are nonnegative functions. Moreover,

$$
|\chi(x, y, z)| \leq u(x)|y|+v(x)|z|+w(x)
$$

for all $x \in[0,1]$ and for all $(y, z) \in \mathbb{R}^{2}$. 
Setting $\alpha=m$, one has to investigate the following inequality:

$$
\left[\frac{m^{2}+m}{1-\left(m^{2}+m\right) \beta(m, 2 n+1)}-1\right] \cdot(1-x)^{m}>0
$$

for all $x \in[0,1]$. In the parameter space $(\alpha, m, n)$, the above inequality is satisfied, for instance, for the case $\alpha=m=n$, whenever

$$
n \geq 1
$$

In this case, the existence of a nontrivial solution $\xi(x) \in C^{2 n}[0,1]$ is guaranteed for problem (20).

\section{Example 3}

Consider the problem for a generic $n \geq 1$

$$
\left\{\begin{aligned}
y^{(2 n)}(x) & =\frac{x^{\alpha}}{2} \frac{y^{3}}{y^{4}+4} \tanh y+\frac{x^{\alpha}}{4}\left(y^{\prime \prime}\right)^{2} e^{-\left(y^{\prime \prime}\right)^{2}}+e^{x}+3 \\
y^{(0)}(0) & =y^{(1)}(0)=\ldots y^{(n)}(0)=0 \\
y^{(n+1)}(1) & =y^{(n+2)}(1)=\ldots y^{(2 n-1)}(1)=0 .
\end{aligned}\right.
$$

This problem satisfies all requirements of Theorem 2. In this example,

$$
\chi(x, y, z)=\frac{x^{\alpha}}{2} \frac{y^{3}}{y^{4}+4} \tanh y+\frac{x^{\alpha}}{4} z^{2} e^{-z^{2}}+e^{x}+3
$$

together with

$$
u(x)=\frac{x^{\alpha}}{2}, v(x)=\frac{x^{\alpha}}{2}, w(x)=e^{x}+3 .
$$

For a generic $\alpha>0$, following assumption 3 of Theorem 3, we have that $(u(x), v(x), w(x)) \in L^{1}[0,1]$ are nonnegative functions. Moreover,

$$
|\chi(x, y, z)| \leq u(x)|y|+v(x)|z|+w(x)
$$

for all $x \in[0,1]$ and $(y, z) \in \mathbb{R}^{2}$. 
We have

$$
u(x)+v(x)=x^{\alpha},
$$

that leads to the relation

$$
\left(\frac{1}{\alpha a+1}\right)^{\frac{1}{a}} \leq \frac{1}{\sum_{k=1}^{2 n-1}\left(\frac{1}{k b+1}\right)^{\frac{1}{b}}}
$$

Setting $a=b=2$, inequality (24) becomes:

$$
\left(\frac{1}{2 \alpha+1}\right)^{\frac{1}{2}} \leq \frac{1}{\sum_{k=1}^{2 n-1}\left(\frac{1}{2 k+1}\right)^{\frac{1}{2}}}=\frac{\sqrt{2}}{\zeta\left(\frac{1}{2}, \frac{3}{2}\right)-\zeta\left(\frac{1}{2}, 2 n+\frac{1}{2}\right)}
$$

where

$$
\zeta(s, q):=\sum_{k=0}^{\infty} \frac{1}{(k+q)^{s}}
$$

is the Hurwitz zeta function, defined for $s \neq 1$ and $\Re(q)>0$. In our problem, it is always well defined since $q>0$ and $s=1 / 2$.

In the parameter space $(\alpha, n)$, setting $\alpha=n$, for instance one obtains that inequality (25) is satisfied whenever

$$
1 \leq n \leq 7 .
$$

Letting $\alpha=n^{2}$ we obtain that inequality (25) is satisfied whenever

$$
n \geq 1 \text {. }
$$

For the above choice of parameters, the existence of a nontrivial solution $\xi(x) \in C^{2 n}[0,1]$ is guaranteed for problem (23).

\section{References}

Ahmad B. \& Ntouyas, S.K. 2012. A study of higher-order nonlinear ordinary differential equations with four-point nonlocal integral boundary conditions. Journal of Applied Mathematics and Computing, 39, pp.97-108. Available at: https://doi.or g/10.1007/s12190-011-0513-0.

Bekri Z. \& Benaicha, S. 2018. Nontrivial solution of a nonlinear sixth-order boundary value problem. Waves, Wavelets and Fractals, 4(1), pp.10-18. Available at: https://doi.org/10.1515/wwfaa-2018-0002. 
Chandrasekhar, S. 1961. Hydrodynamic and Hydromagnetic Stability. New York, NY: Dover. Online ISBN: 9780486319209.

Deimling, K. 1985. Nonlinear Functional Analysis. Berlin, Heidelberg: Springer. Available at: https://doi.org/10.1007/978-3-662-00547-7. Online ISBN: 978-3-66200547-7.

Fabiano, N., Nikolić, N., Shanmugam, T., Radenović, S. \& Čitaković, N. 2020. Tenth order boundary value problem solution existence by fixed point theorem. Journal of Inequalities and Applications, art.number:166. Available at: https://doi. org/10.1186/s13660-020-02429-2.

Isac, G. 2006. Leray-Schauder Type Alternatives, Complementarity Problems and Variational Inequalities. Boston, MA: Springer. Available at: https://doi.org/10 .1007/0-387-32900-5. Online ISBN: 978-0-387-32900-0.

Ma, R. 2000. Existence and uniqueness theorems for some fourth-order nonlinear boundary value problems. International Journal of Applied Mathematics and Computer Science, 23, art.ID:739631. Available at: https://doi.org/10.1155/S016 1171200003057.

Shanmugam, T., Muthiah, M. \& Radenović, S. 2019. Existence of Positive Solution for the Eighth-Order Boundary Value Problem Using Classical Version of Leray-Schauder Alternative Fixed Point Theorem. Axioms, 8(4), art.number:129. Available at: https://doi.org/10.3390/axioms8040129.

Zvyagin, V.G. \& Baranovskii, E.S. 2010. Topological degree of condensing multi-valued perturbations of the $(S)_{+}$-class maps and its applications. Journal of Mathematical Sciences, 170, pp.405-422. Available at: https://doi.org/10.1007/s1 0958-010-0094-8.

СУЩЕСТВОВАНИЕ РЕШЕНИЯ КРАЕВОЙ ЗАДАЧИ ОБЩЕГО ПОРЯДКА С ИСПОЛЬЗОВАНИЕМ ТЕОРЕМЫ ЛЕРЕШАУДЕРА О НЕПОДВИЖНОЙ ТОЧКЕ

Никола Фабиано ${ }^{\text {, Вахид Парванех }}$

а независимый исследователь, г. Рим, Италия, корреспондент,

${ }^{\sigma}$ Исламский университет Азад, фракультет математики, филиал Гилан-э-Герб, г. Гилан-э-Герб,

Исламская Республика Иран 
РУБРИКА ГРНТИ: 27.00.00 МАТЕМАТИКА:

27.29.19 Краевые задачи и задачи на собственные значения для обыкновенных дифференциальных уравнений и систем уравнений,

27.29.21 Аналитическая теория обыкновенных диффреренциальных уравнений и систем уравнений,

27.39.00 Функциональный анализ

ВИД СТАТЬИ: оригинальная научная статья

Резюме:

Введение/цель: В данной статье приведено существование производящей функции Грина для решения краевой задачи произвольного порядка, которая встречается во многих явлениях тепловой конвекции как в атмосфрере, в океанах, так и на поверхности Солнца.

Методы: В статье применена теорема неподвижной точки Лере - Шаудера, с целью подтверждения существования неподвижной точки в данной задаче.

Результаты: Доказано существование решения по произвольному порядку и предлагаются некоторые практические примеры.

Выводы: Краевая задача имеет решение по произвольному n-му порядку.

Ключевые слова: неподвижная точка, краевая задача, теорема Лере - Шаудера о неподвижной точке.

РЕШЕЊЕ ПРОБЛЕМА ГРАНИЧНЕ ВРЕДНОСТИ ОПШТЕГ РЕДА КОЈЕ КОРИСТИ ТЕОРЕМУ НЕПОКРЕТНЕ ТАЧКЕ TИПA LERAY-SCHAUDER

Никола Фабиано ${ }^{\text {, }, \text { Вахид Парванех }}$

а независни истраживач, Рим, Италија, аутор за преписку,

${ }^{\sigma}$ Исламски универзитет Азад, Одељење за математику,

Огранак Гилан-Е-Гхарб, Гилан-Е-Гхарб,

Исламска Република Иран

ОБЛАСТ: математика

ВРСТА ЧЛАНКА: оригинални научни рад 
Сажетак:

Увод/циљ: У раду се приказује постојање генеричке Гринове функције за проблем граничне вредности произвољног реда који се јавља код многих појава конвекције топлоте у, на пример, атмосфрери, океанима и на површини Сунца.

Meтоде: Користи се теорема непокретне тачке типа Leray-Schauder како би се утврдило постојање непокретне тачке у наведеном проблему.

Резултати: Приказано је решење за произвољан ред проблема. Предложени су неки практични примери.

Закључак: Гранични проблем има решење за произвољни n-mu ped.

Кључне речи: непокретна тачка, проблем граничне вредности, теорема непокретне тачке типа Leray-Schauder.

Paper received on / Дата получения работы / Датум пријема чланка: 03.12.2020. Manuscript corrections submitted on / Дата получения исправленной версии работы / Датум достављања исправки рукописа: 01.03.2021.

Paper accepted for publishing on / Дата окончательного согласования работы / Датум коначног прихватања чланка за објављивање: 03.03.2021.

(๖ 2021 The Authors. Published by Vojnotehnički glasnik / Military Technical Courier (http://vtg.mod.gov.rs, http://втг.мо.упр.срб). This article is an open access article distributed under the terms and conditions of the Creative Commons Attribution license (http://creativecommons.org/licenses/by/3.0/rs/).

(c) 2021 Авторы. Опубликовано в "Военно-технический вестник / Vojnotehnički glasnik / Military Technical Courier" (http://vtg.mod.gov.rs, http://втг.мо.упр.срб). Данная статья в открытом доступе и распространяется в соответствии с лицензией "Creative Commons" (http://creativecommons.org/licenses/by/3.0/rs/).

(c) 2021 Аутори. Објавио Војнотехнички гласник / Vojnotehnički glasnik / Military Technical Courier (http://vtg.mod.gov.rs, http://втг.мо.упр.срб). Ово је чланак отвореног приступа и дистрибуира се у складу са Creative Commons лиценцом (http://creativecommons.org/licenses/by/3.0/rs/). 